\title{
Predicting mortality and cost of hematopoeitic stem-cell transplantation
}

\author{
Preditores de mortalidade e custo de transplante de célula-tronco hematopoéticas
}

\author{
Fábio Rodrigues Kerbauy ${ }^{1}$, Leonardo Raul Morelli², Cláudia Toledo de Andrade², \\ Luis Fernando Lisboa ${ }^{2}$, Miguel Cendoroglo $\mathrm{Neto}^{3}$, Nelson Hamerschlak ${ }^{2}$
}

\begin{abstract}
Objective: To evaluate whether the Pretransplantion Assesment of Mortality risk score is associated to transplant costs and can be used not only to predict mortality but also as a cost management tool. Methods: We evaluated consecutively patients submitted to allogeneic $(n=27)$ and autologous $(n=89)$ hematopoietic stem cell-transplantation from 2004 to 2006 at Hospital Israelita Albert Einstein (SP), Brazil. Participants mean age at hematopoietic stem cell-transplantation was 42 (range 1 to 72) years; there were 69 males and 47 females; 30 patients had multiple myeloma; 41 had non-Hodgkin and Hodgkin's lymphomas; 22 had acute leukemia; 6 had chronic leukemia; and 17 had non-malignant disease. The Pretransplantion Assesment of Mortality risk score was applied in all patients using the available web site (http://cdsweb.fhcrc.org/ pam/). Results: Patients could be classified in three risk categories: high, intermediate and low, having significant difference in survival $(p=0.0162)$. The median cost in US dollars for each group was $\$ 281.000, \$ 73.300$ and $\$ 54.400$ for high, intermediate and low risk, respectively. The cost of hematopoietic stem cell-transplantation significantly differed for each Pretransplantin Assesment of Mortality risk group $(p=0.008)$. Conclusion: The validation of the Pretransplantion Assesment of Mortality risk score in our patients confirmed that this system is an important tool to be used in transplantation units, being easy to apply and fully reproducible.
\end{abstract}

Keywords: Hematopoietic stem cells transplantation/economics; Hematopoietic stem cells transplantation/mortality; Costs and cost analysis

\section{RESUMO}

Objetivo: Avaliar se o escore de risco Avaliação de Mortalidade PréTransplante está associado aos custos de transplante e pode ser usado não apenas para predizer a mortalidade, mas também como ferramenta de gerenciamento de custos. Métodos: Foram avaliados consecutivamente 27 pacientes submetidos a transplante alogênico e 89 a transplante autólogo de células tronco hematopoéticas no período de 2004 a 2006 no Hospital Israelita Albert Einstein (SP). A média de idade dos pacientes por ocasião do transplante foi de 42 anos (variação de 1 a 72 anos); 69 eram do gênero masculino e 47 feminino; 30 pacientes tinham mieloma múltiplo, 41 linfoma não Hodgkin e linfoma de Hodgkin; 22 tinham leucemia aguda; 6 tinham leucemia crônica; e 17 doença não maligna. 0 escore de risco Avaliação de Mortalidade Pré-Transplante foi aplicado a todos os pacientes usando um web site fornecido pelos autores (http:// cdsweb.fhcrc.org/pam/). Resultados: Classificaram-se os pacientes em três categorias de risco: alto, intermediário e baixo, apresentando diferença significativa de sobrevivência $(p=0,0162)$. 0 custo médio, em dólares, foi de U\$281.000, U\$ 73.300 e U\$ 54.400 para risco alto, intermediário e baixo, respectivamente. 0 custo do transplante de células tronco hematopoéticas diferiu significantemente para cada grupo de risco segundo o escore Avaliação de Mortalidade Pré-Transplante ( $p=0,008)$. Conclusão: $A$ validação do escore de risco Avaliação de Mortalidade Pré-transplante em nossos pacientes confirmou que esse sistema é uma importante ferramenta a ser usada em unidades de transplante, sendo facilmente aplicável e inteiramente reprodutível.

Descritores: Células-tronco hematopoéticas/economia; Células-tronco hematopoéticas/mortalidade; Custos e análise de custo

\section{INTRODUCTION}

Hematopoietic stem cell-transplantation (HSCT) has the potential to cure patients with different diseases,

\footnotetext{
Study carried out at Hospital Israelita Albert Einstein - HIAE, São Paulo (SP), Brazil.

${ }^{1}$ Bone Marrow Transplant Service, Hospital Albert Einstein - HIAE, São Paulo (SP), Brazil. Universidade Federal de São Paulo - UNIFESP, São Paulo (SP), Brazil.

${ }^{2}$ Clinical Research Center, Hospital Israelita Albert Einstein - HIAE, São Paulo (SP), Brazil.

${ }^{3}$ Hospital Israelita Albert Einstein - HIAE, São Paulo (SP), Brazil.

Corresponding author: Fábio Rodrigues Kerbauy - Avenida Albert Einstein, 627 - Morumbi - Zip code: 05652-000 - São Paulo (SP), Brazil - Phone: (11) 5571-5384 - E-mail: fkerbauy@einstein.br

Received on: Mar 30, 2011 - Accepted on: Sep 15, 2011
}

Conflict of interest: None 
being considered a high complexity and costly procedure. In the last decades, continuous developments in HSCT brought few contributions in reducing treatment relatedmortality after transplantation such as infections and graft-versus-host disease. Consequently, the cost related to the treatment has risen considerably ${ }^{(1-10)}$.

Clinical trials that address HSCT costs are difficult to be conducted because of the wide variation of protocols used in different clinical situations and the supportive care practice. However, several studies have shown an association between the number of complications and transplantation costs ${ }^{(1-10)}$ Therefore, it is possible to predict HSCT cost through the careful pretransplant evaluation and the determination of HSCT possible complications.

A score system known as Pretransplantion Assessment of Mortality (PAM) risk score have been recently developed by Parimon et al. which constitutes an important tool to predict mortality after HSCT and enables to stratify patients in different risk groups according to the patients' pretransplant characteristics ${ }^{(11)}$

\section{OBJECTIVE}

To evaluate whether PAM risk score is associated with transplant cost, and to be used not only to predict mortality but also as a cost management tool.

\section{METHODS}

Retrospective study with 116 patients treated both with autologous and allogeneic HSCT.

Twenty-seven patients submitted to allogeneic and 89 autologous HSCT were consecutively evaluated from 2004 to 2006 at Hospital Israelita Albert Einstein (HIAE), São Paulo, Brazil. Patients mean age at HSCT was 42 (range 1 to 72 ) years, there were 69 males and 47 females. From the total, 30 patients had multiple myeloma, 41 had non-Hodgkin and Hodgkin's lymphomas, 22 had acute leukemia, 6 had chronic leukemia and 17 had non-malignant disease.

The PAM score was applied in all patients using the web site provided by the authors (http://cdsweb. fhcrc.org/pam/) $)^{(1)}$. Briefly, PAM risk score uses eight pretransplantation clinical variables: patient's age, donor type, disease risk, conditioning regimen, forced expiratory volume in 1 second $\left(\mathrm{FEV}_{1}\right)$, carbon monoxide diffusion capacity (DLCO), serum creatinine level, and serum alanine aminotransferase concentration. The PAM risk score can classify 4 different categories according to the probability of death during the first 2 years after transplantation: category 1, less than $25 \%$; category $2,25 \%$ to $50 \%$; category $3,50 \%$ to $75 \%$; and category 4 greater than $75 \%$. In our cohort, patients who were submitted to autologous HSCT $(n=89)$ had no available DLCO. These patients were scored as having normal lung function if their $\mathrm{FEV}_{1}$ was normal with no smoking history and no respiratory clinical and imaging findings.

\section{Transplantation cost and statistical methods}

The total costs associated to the HSCT were calculated from the period of admission to discharge excluding outlier values. Data regarding costs during the days of hospitalization were obtained from the institutional accounting department. Costs were determined from the used item as well as from the procedures' specific costs, and then they were summed. Besides the total cost of care (direct and indirect costs), specific categories of costs were also available, such as: laboratory services, radiologic investigations, pharmacy services, room and hospital stays, blood components, and other services. No costs related to donor search or stem cell or bone marrow collection were used.

For categorical variables, the comparisons between categories were made using the $\chi^{2}$ test, the likelihood ratio test, or Fisher's exact test. For continuous variables the comparisons were made using Wilcoxon two-sample test or Kruskal-Wallis test. Survival curves were constructed using Kaplan-Meier method and compared with the log-rank test. All statistical analyses were performed with the Statistical Analysis System Software (SAS Institute Inc. Cary, North Carolina, USA).

\section{RESULTS}

\section{The PAM risk score and mortality}

Among 27 patients in allogeneic cohort, 15 (55,6\%) died. Because of the low number of patients it was not possible to define the four risk groups. Although, mortality in patients with PAM risk score intermediate 1 and high was $70 \%$ and intermediate 2 and low, $33 \%$, there was no significant statistic difference $(\mathrm{p}=0.1083)$.

Among 89 patients in autologous cohort, 27 (30,3\%) died. Only 5 patients were placed in the low risk group and 22 in the intermediate risk group $(\mathrm{p}=0.040)$.

\section{The PAM risk score and transplantation cost}

According to the PAM risk score, all patients could be classified in three risk categories (high, intermediate and low), having significant difference in survival 
$(\mathrm{p}=0.0162)$. The median cost in US dollars for high, intermediate and low risk group was $\$ 281.000, \$ 73.300$ and $\$ 54.400$ respectively. The cost of HSCT differed significantly for each PAM risk group $(\mathrm{p}=0.008)$ (Figure 1).
These facts are important biases and further prospective validation of our findings should be performed. Another important point about of this study is the specific cost of our private institution that might be widely different from other transplantation centers, which require a

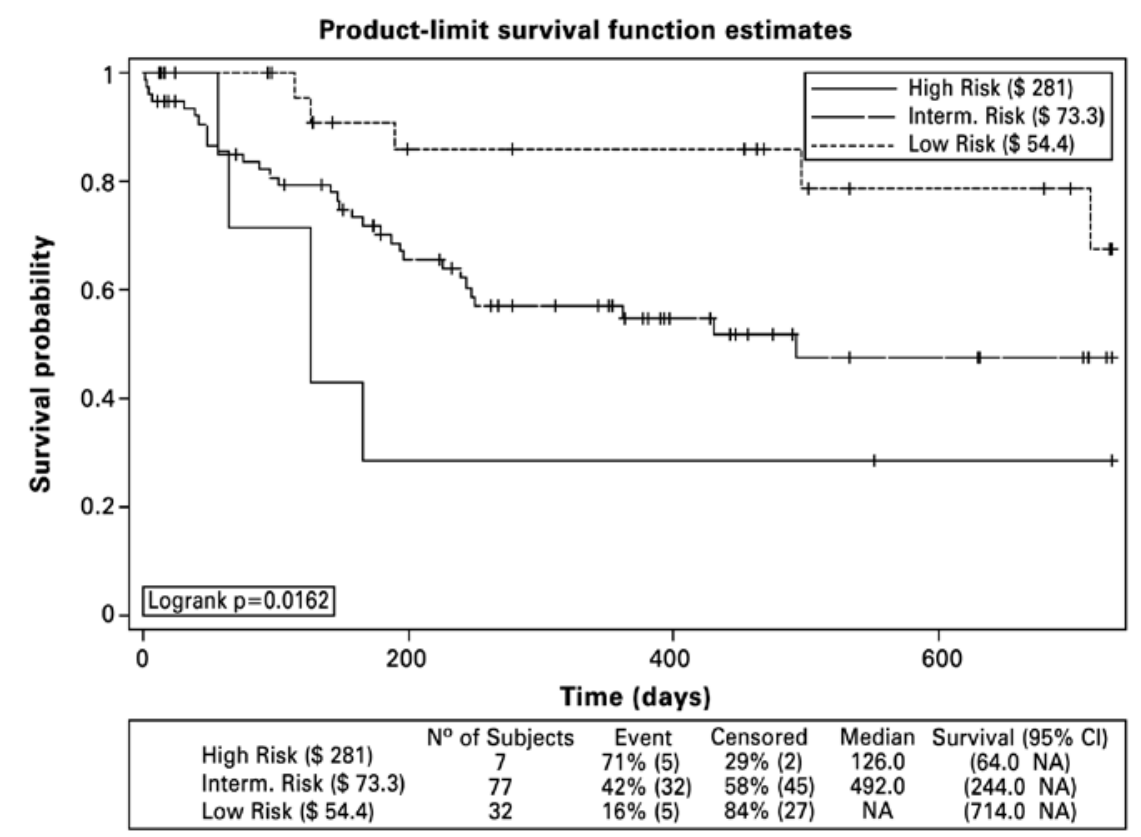

Figure 1. Kaplan-Meier curves showing estimated 2-year overall survival according to Pretransplantion Assessment of Mortality (PAM) score and cost of transplantation in US dollars

\section{DISCUSSION}

The validation of PAM risk score in participants confirmed this system as an important tool to be used in transplantation units, being easy to apply and potentially reproducible.

Few studies have successfully evaluated the relationship between cost and baseline patients characteristics of HSCT and there is no previous report associating reliable score systems with $\operatorname{cost}^{(1-10)}$.

This study showed that the PAM score system is a strategy for predicting not only possible HSCT complications but also cost impact of these complications. Although we could not find any single clinical characteristic associated directly with costs, we believe that patients with more clinical complexity are those who will have more complications associated with higher chance of death and consequently higher treatment cost.

Of note, 89 patients submitted to autologous HSCT had no DLCO available. Since this information is crucial for PAM score calculation, we had to estimate this parameter according to lung function tests, smoking history and lung physical examination and history. We are also aware about the small number of patients. multicenter cohort of patients to achieve more reliable data.

From an economic perspective, applying PAM score before HSCT allowed the identification of patients with different treatment costs, helping in reimbursement negotiations. In philanthropic institutions, a more reasonable use of donations can directly affect health care and benefit a higher number of patients allowing more effective health policies.

From a medical point of view, using a reproducible system that predicts costs and mortality can be useful in defining a treatment plan. It also can help the transplant team to adopt prophylactic measures and to predict complications allowing faster problem detection and prompt treatment.

\section{CONCLUSION}

The use of PAM risk score system in a prospective manner was associated with transplant costs. This study confirmed that this system is an important tool to be used in transplantation units, being easy to apply and fully reproducible, helping to reduce overall costs and increase treatment quality. 


\section{REFERENCES}

1. Bennett $C$, Waters $T$, Stinson T, Almagor 0 , Pavletic $Z$, Tarantolo $S$, et al. Valuing clinical strategies early in development: a cost analysis of allogeneic peripheral blood stem cell transplantation. Bone Marrow Transplant. 1999; 24(5):555-60.

2. Cordonnier C, Maury S, Esperou H, Pautas C, Beaune J, Rodet M, et al. Do minitransplants have minicosts? A cost comparison between myeloablative and nonmyeloablative allogeneic stem cell transplant in patients with acute myeloid leukemia. Bone Marrow Transplant. 2005;36(7):649-54.

3. Espérou $H$, Brunot A, Roudot-Thoraval F, Buzyn A, Dhedin N, Rio B, et al. Predicting the costs of allogeneic sibling stem-cell transplantation: results from a prospective, multicenter, French study. Transplantation. 2004;77(12): 1854-8

4. Lee SJ, Anasetti C, Kuntz KM, Patten J, Antin JH, Weeks JC. The costs and cost-effectiveness of unrelated donor bone marrow transplantation for chronic phase chronic myelogenous leukemia. Blood. 1998;92(11):4047-52.

5. Lee SJ, Klar N, Weeks JC, Antin JH. Predicting costs of stem-cell transplantation. J Clin Oncol. 2000; 18(1):64-71.

6. Lee SJ, Weller E, Alyea EP, Ritz J, Soiffer RJ. Efficacy and costs of granulocyte colony-stimulating factor in allogeneic T-cell depleted bone marrow transplantation. Blood. 1998;92(8):2725-9.

7. Saito AM, Cutler C, Zahrieh D, Soiffer RJ, Ho VT, Alyea EP, et al. Costs of allogeneic hematopoietic cell transplantation with high-dose regimens. Biol Blood Marrow Transplant. 2008;14(2):197-207.

8. Saito AM, Zahrieh D, Cutler C, Ho VT, Antin JH, Soiffer RJ, et al. Lower costs associated with hematopoietic cell transplantation using reduced intensity vs high-dose regimens for hematological malignancy. Bone Marrow Transplant. 2007:40(3):209-17.

9. van Agthoven $M$, Groot MT, Verdonck LF, Löwenberg B, Schattenberg AV, Oudshoorn $M$, et al. Cost analysis of HLA-identical sibling and voluntary unrelated allogeneic bone marrow and peripheral blood stem cell transplantation in adults with acute myelocytic leukaemia or acute Iymphoblastic leukaemia. Bone Marrow Transplant. 2002;30(4):243-51.

10. Stinson TJ, Adams JR, Bishop MR, Kruse S, Tarantolo S, Bennet CL. Economic analysis of a phase III study of G-CSF vs placebo following allogeneic blood stem cell transplantation, Bone Marrow Transplant. 2000; 26(6):663-6.

11. Parimon T, Au DH, Martin PJ, Chien JW. A Risk Score for allogeneic hematopoietic cell transplantation. Ann Internal Med. 2006;144(6):407-14. 